\title{
Management of switchgrass for forage and seed production
}

\author{
JOHN J. BREJDA, JAMES R. BROWN, GARY W. WYMAN, AND WILLIAM K. \\ SCHUMACHER
}

Authors are senior research specialist, professor, and former research specialists, School of Natural Resources, 144 Mumford Hall, University of Missauri, Columbia 65211.

\begin{abstract}
Management of switchgrass (Panicum virgatum L.) for both forage and seed would improve the diversity of options livestock producers have for their stands. Our objective was to evaluate how timing of the forage harvest and $\mathbf{N}$ applications can be used to manage switchgrass for both forage and seed from the same stand. Switchgrass forage was harvested in late May (prior to stem elongation) or mid-June (early boot stage) or left uncut and treated with either single application of $88 \mathrm{~kg} \mathrm{~N} \mathrm{ha}^{-1}$ in the spring or 4-weeks after green-up, or split applications of $44 \mathrm{~kg} \mathrm{~N} \mathrm{ha}^{-1}$ in the spring and $44 \mathrm{~kg} \mathrm{~N} \mathrm{ha}^{-1}$ following defoliation. The late May harvest gave lower yields of higher quality forage whereas the mid-June harvest produced greater yields of lower quality forage. Both the late May and mid-June harvest increased total tiller density compared to uncut plots, but a mid-June harvest decreased reproductive tiller density. Application of $\mathbf{N}$ following defoliation increased both total tiller density and reproductive tiller density but the response was small with a mid-June harvest. A mid-June harvest reduced both seed yield and 100 -seed weights all 3 years. A late May harvest reduced same-year seed yields and 100 -seed weights in 1991 only, when the harvest was taken after stem elongation had initiated. Application of $\mathbf{N}$ following defoliation stimulated plant regrowth, enhancing same-year seed yield. Harvesting switchgrass for forage in the spring prior to stem elongation followed by a post-harvest $N$ application of $44 \mathrm{~kg} \mathrm{~N} \mathrm{ha}^{-1}$ allows producers to manage switchgrass for both forage and seed.
\end{abstract}

Key Words: Panicum virgatum L., warm-season grasses, nitrogen fertilization, tillering, seed quality

Cool-season grasses such as tall fescue (Festuca arundinacea Schreb.) can be managed for both forage and seed from the same stand (Kroth et al. 1977). However, with the exception of old world bluestems (Bothriochloa spp.) (Ahring et al. 1978), limited research has been done on management of warm-season grasses for both forage and seed.

Forage utilization requires a period of defoliation. If the apical meristem is removed during defoliation, both forage regrowth and the quantity and quality of subsequent seed production may be reduced. However, Beaty and Powell (1976) heavily utilized switchgrass ( Panicum virgatum L.) early in the season in Georgia and maintained plant vigor if the growing point was not removed and regrowth allowed to accumulate. In Iowa, early and mid-June defoliation of switchgrass resulted in harvesting high quality forage early in the summer and shifting the major portion of forage production to later in the growing season (George and Obermann

Published as Journal Article 11,871 Agr. Exp. Sta., University of Missouri. The research was conducted under a Missouri Department of Conservation grant (MCC82-01-052). The authors wish to thank Dr. Paul Beuselinck and Dr. David Sleper for use of their facilities in seed separation and cellulase analysis.

Manuscript accepted 10 Jul. 1993.
1989). The greatest regrowth occurred with an early June defoliation because the plants were still vegetative at the time of harvest. This allowed continued growth from existing apical meristems rather than from new shoots. In Colorado, mowing switchgrass early in the spring did not affect seedhead production, but mowing later in the spring progressively reduced the density of seedheads (Sims et al. 1971). Mowing after initiation of stem elongation removed the growing point and stopped shoot growth from elongating tillers, but stimulated production of new tillers from axillary buds.

Switchgrass forage yield, quality, and seed production can be improved with application of nitrogen $(\mathrm{N})$ (Harlan and Kneebone 1953, Hall et al. 1982). Nitrogen fertilization increased tiller density (George and Reigh 1987) and stimulated stem development of switchgrass in Iowa (George and Obermann 1989). Split N applications with a portion of the $\mathrm{N}$ applied in the spring and a second application at the boot stage increased seed yields over that achieved with a single, large spring $\mathrm{N}$ application for both switchgrass in Oklahoma (Harlan and Kneebone 1953) and side-oats grama [Bouteloua curtipendula (Michx. Torr.] in Nebraska (Smika and Newell 1965). Split $N$ applications in which a portion of the $N$ is applied after cutting may stimulate switchgrass recovery following defoliation and same-year seed production. Our objective was to evaluate timing of the forage harvest and $N$ applications to manage switchgrass for both forage and seed from the same stand.

\section{Materials and Methods}

A pure stand of 'Blackwell' switchgrass was established in 1983 at the University of Missouri Agronomy Research Center in Boone County, $18 \mathrm{~km}$ southeast of Columbia, Mo. Following establishment, the stand was burned annually in mid-April prior to greenup. Soil tests of the Mexico silt loam (fine, montmorillonitic, mesic Udollic Ochraqualf) taken in 1989 indicated that phosphorus (P) levels were adequate ( $55 \mathrm{~kg} \mathrm{ha}^{-1}$ Bray $1 \mathrm{P}$ ) but potassium (K) was low $\left(277 \mathrm{~kg} \mathrm{ha}^{-1}\right)$. Fifty-five $\mathrm{kg} \mathrm{K} \mathrm{ha}^{-1}$ was applied to meet University of Missouri soil fertility recommendations for warm-season grasses (Buchholz 1986). Growing season precipitation was recorded for 1989-1991 at the Agronomy Research Center (Table 1).

In 1989 the switchgrass stand was divided into twelve $2.7 \times 27.4$ $\mathrm{m}$ whole-plots and randomly assigned 1 of 3 forage harvest treatments consisting of a late May forage harvest prior to stem elongation, mid-June forage harvest at early boot stage, or no forage harvest, and replicated 4 times. The late May harvests were on 1 May 1989, 29 May 1990, and 28 May 1991. The mid-June harvests were on 14 June in 1989 and 13 June in both 1990 and 1991. The switchyrass stand greened up early in 1991, due to a mild winter and warm spring causing the late May harvest to be taken after initiation of stem elongation when the first node was palpable.

The whole-plots were divided into five $2.7 \times 5.5 \mathrm{~m}$ subplots and 
Table 1. Growing season precipitation at the Agronomy Research Center from April through September for 1989-1991 and 30-year average.

\begin{tabular}{|c|c|c|c|c|}
\hline \multirow[b]{2}{*}{ Month } & \multicolumn{3}{|c|}{ Year } & \multirow{2}{*}{$\begin{array}{l}\text { 30-Year } \\
\text { average }\end{array}$} \\
\hline & 1989 & 1990 & 1991 & \\
\hline & \multicolumn{4}{|c|}{ 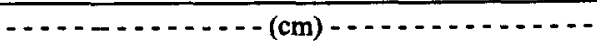 } \\
\hline April & 4.9 & 7.1 & 10.1 & 9.1 \\
\hline May & 13.3 & 28.0 & 14.5 & 11.4 \\
\hline June & 11.1 & 21.7 & 4.7 & 9.6 \\
\hline July & 14.2 & 26.7 & 7.1 & 8.8 \\
\hline August & 19.9 & 9.7 & 11.2 & 7.3 \\
\hline September & 3.6 & 5.2 & 21.0 & 9.4 \\
\hline Total & 67.0 & 98.4 & 68.6 & 55.6 \\
\hline
\end{tabular}

randomly assigned 1 of $5 \mathrm{~N}$ treatments. The $\mathrm{N}$ treatments were: (1) $88 \mathrm{~kg} \mathrm{~N} \mathrm{ha}^{-1}$ at green-up (i.e. the emerging leaves were $2.5-\mathrm{cm}$ long); (2) $88 \mathrm{~kg} \mathrm{~N} \mathrm{ha}^{-1}$ at 4 weeks after green-up; (3) $44 \mathrm{~kg} \mathrm{~N} \mathrm{ha}^{-1}$ at green-up and $44 \mathrm{~kg} \mathrm{~N} \mathrm{ha}^{-1}$ at 4 weeks after green-up; (4) $44 \mathrm{~kg} \mathrm{~N}$ $\mathrm{ha}^{-1}$ at green-up and $44 \mathrm{~kg} \mathrm{~N} \mathrm{ha}^{-1}$ after the forage harvest; and (5) 44 $\mathrm{kg} \mathrm{N} \mathrm{ha}{ }^{-1}$ at 4 weeks after green-up and $44 \mathrm{~kg} \mathrm{~N} \mathrm{ha}^{-1}$ after the forage harvest. Ammonium nitrate (34-0-0) was the $N$ source.

\section{Forage Yield and Quality}

Forage was harvested from a $0.9 \times 4.6$-m strip in each subplot at a $15-\mathrm{cm}$ cutting height and weighed in the field. A subsample was collected from each plot, dried at $65^{\circ} \mathrm{C}$ for 48 hours in a forced-air oven, and weighed to determine percentage dry matter. Dried samples were ground to pass a l-mm screen and analyzed for dry matter digestibility using near infrared reflectance spectroscopy (NIRS). One-third of the samples were digested in a cellulase solution following an acid-pepsin pretreatment (Bughrara and Sleper 1986, Bughrara et al. 1992) to develop appropriate NIRS calibration equations (Brown and Moore 1987). Samples collected in 1990 and 1991 were analyzed for Kjeldahl-N (Bremner and Mulvaney 1982) and reported as crude protein $(\mathrm{N} \times 6.25)$.

\section{Tiller Density and Seed Harvest}

Vegetative and reproductive tillers were counted and seed harvested in September when seed from the top of the panicle had begun to shatter and seed from lower panicle branches were hard and brown. In 1989, a single $1-\mathrm{m}^{2}$ quadrat was randomly located in each subplot, and all reproductive tillers in the frame hand harvested. In 1990 and 1991 , two $0.25-\mathrm{m}^{2}$ quadrants were randomly located in each subplot and the hand harvested material separated into reproductive and vegetative tillers. Seed yield (total caryopsis weight) was obtained by threshing the panicles by hand on a rub-board and separating the seed from the residue with an air column seed blower. Seed quality was estimated by weighing 2 subsamples of 100 caryopses from each subplot. Percentage purity was determined using Association of Official Seed Analysts specifications (AOSA 1978).

\section{Statistical Analysis}

Data were analyzed with analysis of variance using a split-plot design with harvest treatments as the whole plot and $\mathrm{N}$ treatments as the subplot. Harvest effects on reproductive and total tiller density, seed yield, and 100-seed weight were analyzed using orthogonal contrasts to compare the 2 forage-harvest treatments to the no-harvest treatment, and the late May to mid-June forage harvests. Significant differences between the $\mathbf{N}$ treatments were compared using the least significant difference (lsd) test at the 0.05 significance level. Year effects were treated as repeated meásures in time, and partitioning of the sums of squares and appropriate error terms follow Steel and Torrie (1980).

\section{Results and Discussion}

\section{Forage Yield and Quality}

Forage yields increased each year $(P<0.01)$ for both the late May and mid-June harvests (Table 2). The forage yield increase was not associated with yearly precipitation differences since May precipitation was adequate all 3 years. Further, 1991 had the lowest June precipitation all 3 years (Table 1), yet the highest forage yields. This suggests the switchgrass stand thickened with time during the period of the study. The harvest-by-year and $\mathrm{N}$ by year interactions were not significant for forage yields.

The greatest forage yields for both late May and mid-June harvests were obtained with a single application of $88 \mathrm{~kg} \mathrm{~N} \mathrm{ha}^{-1}$ at green-up or split application of $44 \mathrm{~kg} \mathrm{~N} \mathrm{ha}^{-1}$ at green-up and $44 \mathrm{~kg}$ $\mathrm{N} \mathrm{ha}^{-1}$ 4-weeks later (Table 2). The forage harvest by $\mathrm{N}$ treatment interaction was not significant any year.

Forage harvested in late May was $7-8 \%$ more digestible than forage harvested in mid-June all 3 years (Table 2). Forage digestibility was lower in 1991 compared to 1989 and $1990(P<0.01)$ for both the late May and mid-June harvests (Table 2). However, year by forage harvest and year by $\mathrm{N}$ treatment interactions were not significant for forage digestibility.

In 1989 and 1990, the $\mathrm{N}$ treatments interacted with the forage harvests to increase forage digestibility (Table 2). With the late May harvest application of $88 \mathrm{~kg} \mathrm{~N} \mathrm{ha}^{-1}$ at green-up and $44 \mathrm{~kg} \mathrm{~N}$ $\mathrm{ha}^{-1}$ at green-up or $44 \mathrm{~kg} \mathrm{~N} \mathrm{ha}^{-1} 4$ weeks later produced the highest digestibility. This suggests spring $\mathrm{N}$ applications can stimulate a flush of new growth which enhanced overall digestibility of the stand. Spring $\mathbf{N}$ applications increased leaf yields and in vitro dry matter digestibility in switchgrass, big bluestem (Andropogon gerardii Vitman), and indiangrass [Sorghastrum nutans (L.) Nash] in Nebraska (Perry and Baltensperger 1979). The lowest digestibility occurred when the $N$ application was delayed until 4 weeks after green-up. However, with the mid-June harvest, the highest digestibility occurred when $88 \mathrm{~kg} \mathrm{~N}$ ha ${ }^{1}$ was applied 4 weeks after green-up. The lowest digestibility occurred when $44 \mathrm{~kg} \mathrm{~N} \mathrm{ha}^{-1}$ was applied at green-up and $44 \mathrm{~kg} \mathrm{~N}^{-1}$ applied after harvest.

Crude protein concentrations responded to the harvest treatments, $\mathrm{N}$ treatments and year effects $(P<0.01)$, but there were no significant interactions (Table 2). Crude protein was lower $(P<0.05)$ in 1991 compared to 1990 (Table 2), similar to the lower forage digestibility in 1991. The warm spring and earlier green-up in 1991 caused plants to be more mature at harvest, resulting in lower crude protein and digestibility in 1991. Forage harvested in late May was higher in crude protein compared to mid-June.

Timing of the $\mathbf{N}$ application affected crude protein concentrations. With the late May harvest application of $88 \mathrm{~kg} \mathrm{~N} \mathrm{ha}^{-1}$ at green-up or $44 \mathrm{~kg} \mathrm{~N} \mathrm{ha}^{-1}$ at green-up and $44 \mathrm{~kg} \mathrm{~N} \mathrm{ha}^{-1} 4$ weeks later produced the highest crude protein concentrations. With the midJune harvest, application of $88 \mathrm{~kg} \mathrm{~N} \mathrm{ha}^{-1}$ at 4 weeks after green-up or $44 \mathrm{~kg} \mathrm{~N} \mathrm{ha}^{-1}$ at green-up and $44 \mathrm{~kg} \mathrm{~N}^{-1}$ at 4 weeks after green-up produced the highest protein concentrations.

\section{Total and Reproductive Tiller Densities}

Total tiller density increased $24-57 \%$ in response to taking a forage harvest in both $1990(P<0.05)$ and $1991(P<0.01)$ (Table 3). In 1990, the mid-June harvest produced the greatest total tiller density. In 1991, the late May harvest produced the greatest total tiller density, causing a harvest treatment by year interaction $(P<0.01)$. In 1990 , the late May harvest was taken when switchgrass was still vegetative. In 1991, switchgrass had already initiated stem elongation, and the first node was palpable on many tillers during the late May harvest. Increased tillering in 1991 following the late May harvest was due to the more advanced development of the plants at harvest.

Regrowth from switchgrass harvested in late May came primar- 
Table 2. Switchgrass dry matter yields, digestibility and protein concentrations from a late May or mid-June harvest during 1989-1991 at the Agronomy Research Center.

\begin{tabular}{|c|c|c|c|c|c|c|}
\hline \multirow{2}{*}{$\begin{array}{l}\begin{array}{l}\text { N-treatments' } \\
\mathbf{k g ~ N ~ h a}^{-1}\end{array} \\
\end{array}$} & \multicolumn{2}{|c|}{1989} & \multicolumn{2}{|c|}{1990} & \multicolumn{2}{|c|}{1991} \\
\hline & May & June & May & June & May & June \\
\hline $\begin{array}{l}88 \mathrm{GU} \\
88 \mathrm{GU}+4 \text { weeks } \\
44 \mathrm{GU}, 44+4 \text { weeks } \\
44 \mathrm{GU}, 44 \text { harv. } \\
44 \mathrm{GU}+4 \text { weeks, } 44 \text { harv. }\end{array}$ & $\begin{array}{r}1670 \\
1000 \\
1290 \\
1040 \\
960\end{array}$ & $\begin{array}{l}4400 \\
3480 \\
4130 \\
3290 \\
3590\end{array}$ & $\begin{array}{l}1660 \\
1240 \\
1700 \\
1550 \\
1140\end{array}$ & $\begin{array}{c}\text { yields }(1 \\
4310 \\
3650 \\
4430 \\
3700 \\
3290\end{array}$ & $\begin{array}{l}\cdots \cdots \\
2360 \\
1820 \\
2150 \\
2060 \\
1830\end{array}$ & $\begin{array}{l}5170 \\
4240 \\
4860 \\
3900 \\
3960\end{array}$ \\
\hline \multicolumn{7}{|l|}{$P>\mathrm{F}(\mathrm{lsd})$} \\
\hline $\begin{array}{l}\text { Forage harvests } \\
N \text { treatments } \\
\text { Harvest } \times N\end{array}$ & $\begin{array}{l}0.01 \\
0.05 \\
\text { NS }\end{array}$ & $\begin{array}{l}(400) \\
(640)\end{array}$ & $\begin{array}{l}0.01 \\
0.01 \\
\text { NS }\end{array}$ & $\begin{array}{l}(500) \\
(490)\end{array}$ & $\begin{array}{l}0.01 \\
0.01 \\
\text { NS }\end{array}$ & $\begin{array}{l}(950) \\
(550)\end{array}$ \\
\hline $\begin{array}{l}88 \mathrm{GU} \\
88 \mathrm{GU}+4 \text { weeks } \\
44 \mathrm{GU}, 44+4 \text { weeks } \\
44 \mathrm{GU}, 44 \text { harv. } \\
44 \mathrm{GU}+4 \text { weeks, } 44 \text { harv. }\end{array}$ & $\begin{array}{l}55.8 \\
54.4 \\
56.2 \\
55.4 \\
54.7\end{array}$ & $\begin{array}{l}48.3 \\
49.6 \\
48.6 \\
47.3 \\
48.4\end{array}$ & $\begin{array}{l}57.3 \\
56.2 \\
56.8 \\
56.8 \\
54.1\end{array}$ & $\begin{array}{l}\text { ibility }(9 \\
47.8 \\
50.2 \\
48.0 \\
47.7 \\
48.5\end{array}$ & $\begin{array}{l}50.7 \\
49.8 \\
50.5 \\
50.3 \\
49.8\end{array}$ & $\begin{array}{l}43.0 \\
44.2 \\
42.8 \\
42.5 \\
44.2\end{array}$ \\
\hline \multicolumn{7}{|l|}{$P>\mathrm{F}(\mathbf{l s d})$} \\
\hline $\begin{array}{l}\text { Forage harvests } \\
\mathrm{N} \text { treatments } \\
\text { Harvest } \times \mathrm{N}\end{array}$ & $\begin{array}{l}0.01 \\
\text { NS } \\
0.01\end{array}$ & $\begin{array}{l}(0.5) \\
(1.5)\end{array}$ & $\begin{array}{l}0.01 \\
\text { NS } \\
0.05\end{array}$ & $\begin{array}{l}(0.9) \\
(2.6)\end{array}$ & $\begin{array}{l}0.01 \\
\text { NS } \\
\text { NS }\end{array}$ & $(0.7)$ \\
\hline $\begin{array}{l}88 \mathrm{GU} \\
88 \mathrm{GU}+4 \text { weeks } \\
44 \mathrm{GU}, 44+4 \text { weeks } \\
44 \mathrm{GU}, 44 \text { harv. } \\
44 \mathrm{GU}+4 \text { weeks, } 44 \text { harv. }\end{array}$ & - & $\overline{-}$ & $\begin{array}{l}14.8 \\
13.8 \\
14.8 \\
12.8 \\
13.4\end{array}$ & $\begin{array}{l}\text { tein }(\%) \\
10.4 \\
12.3 \\
11.7 \\
9.1 \\
10.4\end{array}$ & $\begin{array}{r}11.5 \\
10.5 \\
11.3 \\
9.3 \\
10.4\end{array}$ & $\begin{array}{l}7.4 \\
8.2 \\
8.0 \\
5.9 \\
7.9\end{array}$ \\
\hline \multicolumn{6}{|l|}{$P>\mathrm{F}(\mathbf{l s d})$} & 7.5 \\
\hline $\begin{array}{l}\text { Forage harvests } \\
N \text { treatments } \\
\text { Harvest } \times N\end{array}$ & $\cdot$ & & $\begin{array}{c}0.01 \\
0.01 \\
\text { NS }\end{array}$ & $\begin{array}{l}(1.2) \\
(1.2)\end{array}$ & $\begin{array}{l}0.01 \\
0.01 \\
\text { NS }\end{array}$ & $\begin{array}{l}(0.5) \\
(1.0)\end{array}$ \\
\hline
\end{tabular}

'Time of $\mathrm{N}$ application was varied. $\mathrm{GU}=\mathrm{green}$ up; $\mathrm{GU}+4$ weeks=4 weeks after green up; harv. =harvest.

ily from apical meristems not removed in the harvest, with only a small proportion $(<10 \%)$ of regrowth arising from basal buds on the crown. In contrast, regrowth from plants harvested in midJune came from new tillers arising from basal buds on the crown and from aerial tillers produced by axillary buds at the uppermost undefoliated node of previously elongating tillers (Heidemann and Van Riper 1967). Aerial tillers are the least productive of new tillers (Waller et al. 1985), and we noted that few of these tillers produced an inflorescence.

The $\mathrm{N}$ treatments did not affect total tiller density in the absence of a forage harvest. However, when $\mathrm{N}$ was applied shortly before or after the forage harvest, it increased total tiller densities, causing a significant forage harvest by $N$ treatment interaction in 1991 (Table 3). George and Reigh (1987) reported spring $\mathrm{N}$ applications increased switchgrass tiller density, which they attributed to increased shoot initiation, meristem survival and tiller development. The results from our study suggest that $\mathrm{N}$ application may also increase tiller density if applied immediately following defoliation.

Reproductive tiller densities changed in response to taking a forage harvest, but the effect varied between 1990 and 1991 resulting in a harvest-treatment-by-year-interaction $(P<0.05)$ (Table 3). A mid-June harvest reduced reproductive tiller density by $28 \%$ in 1990 and 53\% in 1991 (Table 3). A late May forage harvest did not affect reproductive tiller density in 1990 , but caused a $19 \%$ reduc- tion in 1991 (Table 3).

The different response in reproductive tiller density to the late May harvest in 1990 and 1991 was due to the different phenological stage of development of the grass at the time of harvest. In 1990 the late May harvest was taken prior to stem elongation. However, in 1991 , some switchgrass tillers had initiated stem elongation and the first node was palpable by the time the harvest was taken. Switchgrass is characterized by a high proportion of reproductive shoots that elevate early in the season (Waller et al. 1985). In Colorado, mowing switchgrass early in the spring did not affect seedhead production, but mowing after plants initiated stem elongation removed the growing point and stopped shoot growth from elongating tillers (Sims et al. 1971). The growing point was removed from elongating tillers in 1991 due to the more advanced development of the stand, causing a greater reduction in the density of reproductive tillers in 1991 .

The $\mathrm{N}$ treatments did not affect reproductive tiller density in 1990 , but there was a harvest-treatment by-N-treatment interaction $(P<0.05)$ for reproductive tiller density in 1991 (Table 3). With the late May harvest the greatest reproductive tiller density occurred when $88 \mathrm{~kg} \mathrm{~N} \mathrm{ha}^{-1}$ was applied 4 weeks after green-up. This resulted in $\mathbf{N}$ being applied about the time plants were defoliated. With the mid-June harvest the greatest reproductive tiller density occurred when $44 \mathrm{~kg} \mathrm{~N} \mathrm{ha}^{-1}$ was applied in the spring and 44 $\mathrm{kg} \mathrm{Nha}^{-1}$ applied after the forage harvest. This suggests that $\mathrm{N}$ applica- 
Table 3. Reproductive and total tiller density of switchgrass harvested for forage in late May, mid-June, or not harvested and counted in September of 1990 and 1991 at the Agronomy Research Center.

\begin{tabular}{|c|c|c|c|c|c|c|}
\hline \multirow{2}{*}{$\begin{array}{l}\text { N-treatments } \\
\mathrm{kg} \mathrm{N}^{1} \mathrm{ha}^{-1}\end{array}$} & \multicolumn{3}{|c|}{1990} & \multicolumn{3}{|c|}{1991} \\
\hline & late May & mid-June & No harvest & late May & mid-June & Harvest \\
\hline $\begin{array}{l}88 \mathrm{GU} \\
88 \mathrm{GU}+4 \text { weeks } \\
44 \mathrm{GU}, 44+4 \text { weeks } \\
44 \mathrm{GU}, 44 \text { harv. } \\
44 \mathrm{GU}+4 \text { weeks, } 44 \text { harv. }\end{array}$ & $\begin{array}{l}540 \\
540 \\
350 \\
420 \\
420\end{array}$ & $\begin{array}{l}530 \\
630 \\
500 \\
630 \\
630\end{array}$ & $\begin{array}{l}370 \\
320 \\
350 \\
390 \\
430\end{array}$ & $\begin{array}{l}\text { rs density ( } \\
570 \\
750 \\
590 \\
600 \\
630\end{array}$ & $\begin{array}{l}420 \\
550 \\
640 \\
630 \\
690\end{array}$ & $\begin{array}{l}430 \\
430 \\
370 \\
410 \\
370\end{array}$ \\
\hline \multicolumn{7}{|l|}{$P>\mathrm{F}$ (lsd) } \\
\hline $\begin{array}{l}\text { Harvest vs no harvest } \\
\text { May vs mid-June harvest } \\
\text { N-treatments } \\
\text { Harvest } \times \mathrm{N}\end{array}$ & & $\begin{array}{l}0.05 \\
\text { NS } \\
\text { NS } \\
\text { NS }\end{array}$ & & & $\begin{array}{l}0.01 \\
\text { NS } \\
\text { NS } \\
0.05\end{array}$ & $(200)$ \\
\hline $\begin{array}{l}88 \mathrm{GU} \\
88 \mathrm{GU}+4 \text { weeks } \\
44 \mathrm{GU}, 44+4 \text { weeks } \\
44 \mathrm{GU}, 44 \text { harv. } \\
44 \mathrm{GU}+4 \text { weeks, } 44 \text { harv. }\end{array}$ & $\begin{array}{l}330 \\
370 \\
270 \\
260 \\
310\end{array}$ & $\begin{array}{l}160 \\
210 \\
170 \\
260 \\
230\end{array}$ & $\begin{array}{l}280 \\
250 \\
300 \\
300 \\
320\end{array}$ & $\begin{array}{l}\text { tillers dens } \\
170 \\
310 \\
240 \\
250 \\
320\end{array}$ & $\begin{array}{r}90 \\
130 \\
110 \\
190 \\
230\end{array}$ & $\begin{array}{l}340 \\
340 \\
280 \\
320 \\
300\end{array}$ \\
\hline \multicolumn{7}{|l|}{$P>\mathrm{F}$ (lsd) } \\
\hline $\begin{array}{l}\text { Harvest vs no harvest } \\
\text { May vs mid-June harvest } \\
\text { N-treatments } \\
\text { Harvest } \times \mathrm{N}\end{array}$ & & $\begin{array}{l}\text { NS } \\
0.01 \\
\text { NS } \\
\text { NS }\end{array}$ & & & $\begin{array}{l}0.01 \\
0.01 \\
0.05 \\
0.05\end{array}$ & $\begin{array}{r}(60) \\
(100)\end{array}$ \\
\hline
\end{tabular}

Time of $\mathrm{N}$ application was varied. $\mathrm{GU}=\mathrm{green}$ up; $\mathrm{GU}+4$ weeks $=4$ weeks after green up; harv.=harvest.

tions immediately after defoliation may help stimulate new growth and development of new reproductive tillers. There were no significant interactions between years and forage harvests or years and $\mathrm{N}$ treatments for reproductive tiller density.

\section{Seed Yield and Quality}

Seed yields from plots not harvested for forage declined $\left(P<0.01\right.$ ) from $620 \mathrm{~kg} \mathrm{ha}^{-1}$ in 1989 to $470 \mathrm{~kg} \mathrm{ha}^{-1}$ in 1991 (Table 4). The switchgrass stand was established in 1983 and was 8 years old by the end of the study. Decline in seed yields over years reflect stand aging and a loss of seed productivity with time (Cornelius 1950).

IIarvesting forage in late May produced a small decrease (13-26\%) in seed yields in 1989 and 1990 but a large decrease $(70 \%)$ in seed yields in 1991 . The $70 \%$ decline in seed yields with a late May forage harvest in 1991 was due to the more advanced development of the switchgrass stand at the time of harvest, resulting in defoliation of a higher percentage of elongating tillers.

The $\mathrm{N}$ treatments interacted $(P<0.05)$ with the forage harvests to increase seed yields in 1989 and 1991 (Table 4). In the absence of a forage harvest, application of $88 \mathrm{~kg} \mathrm{~N} \mathrm{ha}^{-1}$ at green-up or $44 \mathrm{~kg} \mathrm{~N}$ $\mathrm{ha}^{-1}$ at green-up and $44 \mathrm{~kg} \mathrm{~N} \mathrm{ha}^{-1} 4$ weeks after green-up produced the greatest seed yields (Table 4). Delaying the first $\mathrm{N}$ application until 4 weeks after green-up gave the lowest seed yields all 3 years. These results differ from those by Harlan and Kneebone (1953) in Oklahoma where a split application of $44 \mathrm{~kg} \mathrm{~N} \mathrm{ha}^{-1}$ in the spring followed by $33 \mathrm{~kg} \mathrm{~N} \mathrm{ha}^{-1}$ at the boot stage produced greater switchgrass seed yields than a single application of $77 \mathrm{~kg} \mathrm{~N} \mathrm{ha}^{-1}$ in the spring.

With the late May forage harvest, the greatest seed yields were achieved with an application of $88 \mathrm{~kg} \mathrm{~N}^{-1}$ at 4 weeks after green-up, which is about the time the forage was harvested. With the mid-June forage harvest the greatest seed yields were achieved when $\mathbf{N}$ was applied after the forage harvest. However, the increase in seed production remained small. The benefits of post-harvest $\mathbf{N}$ fertilization in stimulating new tiller development in mid-June when the plants are already in the boot stage was insufficient to compensate for the negative effects of defoliation (Table 4).

The mid-June forage harvest reduced 100-seed weights compared to either a late May or no forage harvest in both 1989 $(P<0.01)$ and $1990(P<0.06)$ (Table 4). In 1991 both the late May and mid-June harvests reduced 100-seed weights, causing a forageharvest by year interaction $(P<0.01)$ (Table 4$)$.

Two possible explanations for differences in 100-seed weights following the late May harvest in 1991 compared to 1989 or 1990 are the more advanced stage of development of the switchgrass stand at the time of harvest in 1991, and unusually low June precipitation in 1991. Low rainfall could have slowed plant growth and replacement of leaf area following defoliation, reducing photosynthate available for seed development and filling as well as replenishing carbohydrate reserves. A reduction in seed weight reduces total seed yield and is associated with poor seed quality. Kneebone and Cremer (1955) reported that smaller switchgrass seeds resulted in smaller, less vigorous seedlings compared to larger seeds.

The $\mathrm{N}$ treatments had no affect on 100 -seed weights nor were there any significant $N$ treatment by harvest and $N$ treatment by year interactions (Table 4). This response is consistent with those reported by both Harlan and Kneebone (1953) and Kassel et al. (1985) who reported that $N$ had no effect on switchgrass seed weight regardless of either the rate or timing of application.

\section{Conclusion}

Our results indicate that switchgrass should not be defoliated in the spring in Missouri if high seed yields are an important objective. However, if seed and livestock producers with switchgrass stands are willing to accept moderate (13-26\%) reductions in seed yields, they have the option of managing their stands for both forage and seed production. 
Table 4. Seed yields and 100-seed weights from switchgrass harvested for forage in late May, mid-June or not harvested during $1989-1991$ at the Agronomy Research Center.

\begin{tabular}{|c|c|c|c|c|c|c|c|c|c|}
\hline \multirow{2}{*}{$\begin{array}{l}\mathrm{N} \text {-treatments }{ }^{1} \\
\mathbf{k g ~ N ~ h a}^{-1}\end{array}$} & \multicolumn{3}{|c|}{1989} & \multicolumn{3}{|c|}{1990} & \multicolumn{3}{|c|}{1991} \\
\hline & late May & mid-June & No harvest & late May & mid-June & No harvest & late May & mid-June & No harvest \\
\hline $\begin{array}{l}88 \mathrm{GU} \\
88 \mathrm{GU}+4 \text { weeks } \\
44 \mathrm{GU}, 44+4 \text { weeks } \\
44 \mathrm{GU}, 44 \text { harv. } \\
44 \mathrm{GU}+4 \text { weeks, } 44 \text { harv. }\end{array}$ & $\begin{array}{l}400 \\
520 \\
460 \\
420 \\
480\end{array}$ & $\begin{array}{r}40 \\
80 \\
40 \\
120 \\
50\end{array}$ & $\begin{array}{l}720 \\
590 \\
730 \\
660 \\
420\end{array}$ & $\begin{array}{l}-\cdots \text { See } \\
510 \\
600 \\
400 \\
420 \\
510\end{array}$ & $\begin{array}{c}\text { yields }(\mathrm{kg} \\
60 \\
90 \\
60 \\
110 \\
80\end{array}$ & $\begin{array}{c}\left.\mathrm{a}^{-1}\right) \cdots \\
660 \\
390 \\
700 \\
460 \\
570\end{array}$ & $\begin{array}{r}80 \\
190 \\
120 \\
130 \\
180\end{array}$ & $\begin{array}{r}50 \\
90 \\
50 \\
90 \\
110\end{array}$ & $\begin{array}{l}560 \\
510 \\
450 \\
430 \\
410\end{array}$ \\
\hline \multicolumn{2}{|l|}{$P>\mathrm{F}($ lsd $)$} & & 620 & 490 & 80 & 560 & 140 & 80 & 470 \\
\hline $\begin{array}{l}\text { Harvest vs no harvest } \\
\text { May vs mid-June harvest } \\
\mathrm{N} \text { treatments } \\
\text { Harvest } \times \mathrm{N}\end{array}$ & & $\begin{array}{l}0.01 \\
0.01 \\
\text { NS } \\
\text { NS }\end{array}$ & & & $\begin{array}{l}0.01 \\
0.01 \\
\text { NS } \\
\text { NS }\end{array}$ & & & $\begin{array}{l}0.01 \\
0.05 \\
\text { NS } \\
\text { NS }\end{array}$ & \\
\hline $\begin{array}{l}88 \mathrm{GU} \\
88 \mathrm{GU}+4 \text { weeks } \\
44 \mathrm{GU}, 44+4 \text { weeks } \\
44 \mathrm{GU}, 44 \text { harv. } \\
44 \mathrm{GU}+4 \text { weeks, } 44 \text { harv. }\end{array}$ & $\begin{array}{l}149 \\
112 \\
113 \\
137 \\
133\end{array}$ & $\begin{array}{r}85 \\
102 \\
73 \\
74 \\
76\end{array}$ & $\begin{array}{l}130 \\
129 \\
135 \\
127 \\
125\end{array}$ & $\begin{array}{l}113 \\
103 \\
115 \\
115 \\
108\end{array}$ & $\begin{array}{l}\text { seed weight } \\
94 \\
81 \\
91 \\
86 \\
94\end{array}$ & $\begin{array}{c}(\mathrm{mg}) \\
130 \\
105 \\
99 \\
118 \\
113\end{array}$ & $\begin{array}{l}126 \\
121 \\
125 \\
118 \\
124\end{array}$ & $\begin{array}{l}126 \\
119 \\
123 \\
121 \\
123\end{array}$ & $\begin{array}{l}130 \\
126 \\
138 \\
139 \\
130\end{array}$ \\
\hline \multicolumn{9}{|l|}{$P>\mathrm{F}(\mathrm{lsd})$} & 133 \\
\hline $\begin{array}{l}\text { Harvest vs no harvest } \\
\text { May vs mid-June harvest } \\
\mathrm{N} \text { treatments } \\
\text { Harvest } \times \mathrm{N}\end{array}$ & & $\begin{array}{l}0.01 \\
0.01 \\
\text { NS } \\
\text { NS }\end{array}$ & & & $\begin{array}{l}\text { NS } \\
0.06 \\
\text { NS } \\
\text { NS }\end{array}$ & & & $\begin{array}{l}0.06 \\
\text { NS } \\
\text { NS } \\
\text { NS }\end{array}$ & \\
\hline
\end{tabular}

'Time of $\mathrm{N}$ application was varied. $\mathrm{GU}=\mathrm{green}$ up; $\mathrm{GU}+4$ weeks=4 weeks after green up; harv. =harvest.

Producers managing switchgrass stands for both forage and seed should apply $\mathbf{N}$ at green-up in the spring and can cut or graze switchgrass until shortly before it initiates stem elongation. However, results from the 1991 harvest indicate that the timing of the late May forage harvest is critical if both forage and seed are desired. Forage must not be harvested after switchgrass begins stem elongation to ensure apical meristems are not removed. Delaying the forage harvest until after stem elongation begins will severely reduce same year seed yields. The mid-June forage harvest taken at the boot stage reduced seed yields $83-89 \%$ each year and does not appear to be a viable option if a seed harvest is planned. At the stem elongation stage a second $\mathrm{N}$ application should be given (in our study $44 \mathrm{~kg} \mathrm{~N} \mathrm{ha}^{-1}$ ) to stimulate regrowth and the stand rested to allow for replacement of leaf area and carbohydrate reserves. When plants reach the seedhead emergence stage, producers should evaluate their stands to determine if they want to continue resting it until fall and harvest a seed crop or forgo a seed harvest and utilize the forage regrowth for either grazing or hay. A spring defoliation of switchgrass can be used to shift the major portion of switchgrass forage production later into the growing season with no serious reduction in forage quality (George and Obermann 1989).

Finally, if switchgrass stands are to be managed for both forage production and wildlife habitat (Clubine 1986), a late May forage harvest will work well. This allows livestock producers to utilize the high quality spring and early summer forage while providing sufficient rest for good production of the taller reproductive tillers and robust clumping structure that provides good quality cover.

\section{Literature Cited}

Ahring, R.M., C.M. Taliaferro, and C.C. Russell. 1978. Establishment and management of old world bluestem grasses for seed. Okla. Agr. Exp. Sta. Tech. Bull. T-149.

Association of Official Seed Analysts. 1978. Rulcs for testing seeds. J. Seed Tech. 3:29-118.
Beaty, E.R., and J.D. Powell. 1976. Response of switchgrass (Panicum virgatum L.) to clipping frequency. J. Range Manage. 29:132-135.

Bremner, J.M., and C.S. Mulvaney. 1982. Nitrogen-Total. p. 595-624. In: A.L. Page, R.H. Miller, and D.R. Keeney (ed.) Methods of Soil Analysis, Part 2. Chemical and microbial properties. Amer. Soc. Agron., Soil Sci. Soc. Amer., Madison, Wisc.

Brown, W.F., and J.E. Moore. 1987. Analysis of forage research samples utilizing a combination of wet chernistry and near infrared reflectance spectroscopy. J. Anim. Sci, 64:271-282.

Buchholx, D.D. 1986. Soil test interpretations and recommendations handbook. Univ. of Missouri, Col. Agr. Dep. Agron. mimeo.

Bughrara, S.S., and D.A. Sleper. 1986. Digestion of several temperate forage species by a prepared cellulase solution. Agron. J. 78:94-98.

Bughrara, S.S., D.A. Sleper, and P.R. Beuselinck. 1992. Comparison of cellulase solutions for use in digesting forage samples. Agron. J. 84:631-636.

Clubine, S. 1986. Multiple use for native warm-season grasses, p. 10-11. In: Warm season grasses: Balancing forage programs in the northeast and southern corn belt. Soil Conserv. Soc. Amer., Ankeny, Iowa.

Cornelius, D.R. 1950. Seed production of native grasses under cultivation in eastern Kansas. Ecol. Monogr. 20:3-29.

George, J.R., and D. Obermann. 1989. Spring defoliation to improve summer supply and quality of switchgrass. Agron. J. 81:47-52.

George, J.R., and G.S. Reigh. 1987. Spring growth and tiller characteristics of switchgrass. Can. J. Plant Sci. 67:167-174.

Hall, K.E., J.R. George, and R.R. Riedl. 1982. Herbage dry matter yields of switchgrass, big bluestem, and indiangrass with $\mathbf{N}$ fertilization. Agron. J. 74:47-51.

Harlan, J.R., and W.R. Kneebone. 1953. Effect of various methods and rates of nitrogen application on seed yield of switchgrass (Panicum virgatum L.). Agron. J. 45:385-386.

Heidemann, G.S., and G.E. Van Riper. 1967. Bud activity in the stem, crown, and rhizome tissue of switchgrass. J. Range Manage. 20:236-241.

Kassel, P.C., R.E. Mullen, and T.B. Bailey. 1985. Seed yield response of three switchgrass cultivars for different management practices. Agron. J. 77:214-218.

Kneebone, W.R., and C.L. Cremer. 1955. The relationship of seed size to seedling vigor in some native grass species. Agron. J. 51:515-518.

Kroth, E., R. Mattas, L. Meinke, and A. Matches. 1977. Maximizing production potential of tall fescue. Agron. J. 69:319-322. 
Perry, L.J., and D.D. Baltensperger. 1979. Leaf and stem yields and forage quality of three N-fertilized warm-season grasses. Agron. J. 71:355-358. Sims, P.L., L.J. Ayuko, and D.N. Hyder. 1971. Developmental morphology of switchgrass and sideoats grama. J. Range Manage. 24:357-360. Smika, D.E., and L.C. Newell. 1965. Irrigation and fertilization practices for seed production from established stands of side-oats grama. Univ. Nebraska Agr. Exp. Sta. Bull. 218.
Steel, R.G.D., and J.H. Torrie. 1980. Principles and procedures of statistics. McGraw-Hill Publ. Co., N.Y.

Waller, S.S., L.E. Moser, and P.E. Reece. 1985. Understanding grass growth: The key to profitable livestock production. Trabon Printing Co., Inc., Kansas City, Mo.

\footnotetext{
Statement of Ownership, Management, and Circulation

(Act. of August 12, 1970, Sec. 3685, Title 39, United States Code)

1. Title of Publication: Journal of Range Management

2. Date of Filing: September 30, 1993

3. Frequency of Issue: Bimonthly

4. Location of Office of Publication: 1839 York Street, Denver, Colo. 80206

5. Location of General Business Office: Same

6. Name and Address of:

Publisher: Society for Range Management, 1839 York Street, Denver, Colo. 80206

Editor: Gary Frasier, 1300 Wheatridge Court, Loveland, Colo. 80537.

Managing Editor: Dr. Charles B. Rumburg, 1839 York Street, Denver, Colo. 80206

7. Owner: Society for Range Management, 1839 York Street, Denver, Colo. 80206

8. Known Bondholders, Mortgagees, etc.: NONE

9. For Completion by Nonprofit Organizations Authorized to Mail at Special Rates: The purpose, function, and nonprofit status of this organization and the exempt status for Federal income tax purposes have not changed during preceding 12 months.

10. Extent and Nature of Circulation
}

\begin{tabular}{|c|c|c|}
\hline & $\begin{array}{l}\text { Avg. for } \\
12 \text { months }\end{array}$ & $\begin{array}{l}\text { Actual for } \\
\text { issue neares } \\
\text { filing date }\end{array}$ \\
\hline $\begin{array}{l}\text { A. Total copies printed } \\
\text { B. Paid Circulation }\end{array}$ & 5,648 & 5,545 \\
\hline $\begin{array}{l}\text { 1. Dealers, counter sales } \\
\text { 2. Mail subscriptions }\end{array}$ & $\begin{array}{c}0 \\
5,061\end{array}$ & $\begin{array}{c}0 \\
5,125\end{array}$ \\
\hline C. Total paid circulation & 5,061 & 5,125 \\
\hline D. Free distribution & 18 & 18 \\
\hline E. Total distribution & 5,079 & 5,143 \\
\hline F. Copies not distributed & 569 & 402 \\
\hline G. Total & 5,648 & 5,545 \\
\hline
\end{tabular}

I certify that the statements made by me above are correct and complete.-Charles B. Rumburg, Managing Editor. 